\title{
Heavy metal pollution among autoworkers. II. Cadmium, chromium, copper, manganese, and nickel
}

\section{J. CLAUSEN ${ }^{1}$ AND S. C. RASTOGI²}

From the Institute of Hygiene, Preventive and Social Medicine, Odense University, Odense, Denmark

ABSTRACT Garages and auto-repair workshops may be polluted with other heavy metals besides lead. Blood of autoworkers with high lead content was analysed for cadmium, chromium, copper, manganese, nickel, ALAD activity and carboxyhaemoglobin level. Cadmium and copper levels in blood of autoworkers were comparable with those of the control subjects while chromium and nickel levels were significantly higher ( $\mathrm{P}<0.01$ for both metals), and scattered raised values of manganese were found. There was no significant mutual correlation between levels of various heavy metals determined in whole blood. High copper levels were slightly related to decreasing ALAD activity $(P<0 \cdot 1)$. Nineteen per cent of autoworkers were found to have an abnormally high blood level of carboxyhaemoglobin. The amount of particulate heavy metal in autoworkshop air was not related to biochemical abnormalities found in the autoworkers. Various sources of pollution of these heavy metals in autoworkshops are discussed.

The toxicity of heavy metals such as cadmium, chromium, copper, manganese and nickel has recently been evaluated (Jonderko et al., 1971; McNeely et al., 1971; Tolonen, 1972; Albert et al., 1973; Evans, 1973; Fleming et al., 1974; Fleischer et al., 1974; McHowell et al., 1974; Ottolenghi et al., 1974; Fassett, 1975; Royle, 1975 a, b; Samitz and Katz, 1975; Schoental, 1975). Sources of lead pollution in auto-repair shops have been described in Part I (Clausen and Rastogi, 1977). Analysis of motor exhausts has shown that besides various hydrocarbons, nitrogen oxides and lead, they often contain manganese, vanadium and boron. Information about heavy metal pollution in autoworkshops is, however, lacking (World Health Organization, 1969).

The fumes given off by metal-coated welding electrodes contain zinc, iron, chromium, copper, lead, titanium and vanadium (Sanderson, 1968; Steel, 1968). The use of chromium-pigment based paints, the addition of complex organometallic compounds to lubricants and oils and the use of compounds such as methylcyclopentadienyl manganese tricarbonyl as an additive to oils may also be

${ }^{1}$ Present address: Laboratory of Biochemistry and Toxicology, Institute of Life Science, Faculty of Natural Sciences, Building 161, University of Roskilde, Denmark.

'Present address: The Neurochemical Institute, 58 Rådmandsgade, DK 2200 Copenhagen N, Copenhagen.

Received for publication 1 June 1976

Accepted for publication 27 July 1976 sources of heavy metal pollution in garages (Tolonen, 1972; Haar et al., 1975). Finally, the steel used by such workers contains varying amounts of nickel and chromium which may cause pollution. Samitz and Katz (1975) have shown that nickel is released from prostheses by the action of sweat, blood and physiological saline.

This paper describes the determination of cadmium, chromium, copper, manganese and nickel levels in whole blood from autoworkers and the investigation of sources of pollution. The effect of automobile exhaust gases on carboxyhaemoglobin levels in autoworkers is also examined.

\section{Material and methods}

\section{MATERIAL}

The subjects and normal controls were those described in Part I (Clausen and Rastogi, 1977). Analysis for other heavy metals was carried out on autoworkers with high blood lead levels.

\section{METHODS}

Heavy metals in particulate air samples and in whole blood were determined by flameless atomic absorption spectrophotometry (Melgaard et al., 1976a). Dust and oil samples treated with an acid mixture for analysis of lead were used for determination of the other heavy metals (Clausen and Rastogi, 1977). Standard curves were prepared by adding known amounts of each of the metals under investigation 
to a fixed amount of blood, dust or oil, with subsequent analysis to determine recovery of the metal. Cadmium was determined at $228 \cdot 8 \mathrm{~nm}$, chromium at $357.8 \mathrm{~nm}$, copper at $324.7 \mathrm{~nm}$, manganese at $279.5 \mathrm{~nm}$ and nickel at $232.0 \mathrm{~nm}$ using specific single-element hollow cathode lamps from PerkinElmer. ALAD activity in the blood of autoworkers has been described previously (Clausen and Rastogi, 1977). Carboxyhaemoglobin (COHb) in fresh blood samples was assayed by the classical method (Bauer et al., 1974). Statistical analysis was as in Part I (Clausen and Rastogi, 1977). All data had mean and median values identical within the $5 \%$ limit.

\section{Results}

Heavy metal levels in whole blood from autoworkers and from control subjects are shown in Table 1. Heavy metal levels in individual control subjects have been reported previously (Melgaard et al., 1976a).

Wilcoxon's test showed that levels of chromium and nickel were significantly higher in whole blood of autoworkers than of controls $(P<0.01$ for both metals) while the levels of cadmium, copper and manganese were identical. The mean nickel content in whole blood of the autoworkers was three times higher than that of the controls. Forty per cent, $24 \%$ and $13 \%$ of autoworkers had levels of nickel, chromium and manganese respectively that were higher than the upper range of the normal subjects.

If lead and other pollutant heavy metals have a common source, the individual blood levels of such metals may show a correlation. However, no significant correlation was observed between the levels of lead and of chromium, copper, manganese and nickel, but there was a slight correlation between copper and nickel (Spearman's rank correlation coefficient $r=0.4681, P<0.1)$. Chromium and manganese levels did not correlate with those of nickel or with copper, and chromium levels did not correlate with manganese levels.

The ALAD activity in blood was depressed by lead but a corresponding effect was not observed with other heavy metals with the exception of copper (Spearman's rank correlation coefficient $r=0.4423$, $P \leqq 0 \cdot 1)$.

Analysis of air samples showed that air in all types of workshops was contaminated with the heavy metals under investigation compared to ambient air outside the workshops (Table 2). The heavy metal concentration in workshop air samples did not exceed the TLV $\left(0.1 \mathrm{mg} \mathrm{Cd}, 0.1 \mathrm{mg} \mathrm{CrO}_{3}\right.$, $5.0 \mathrm{mg} \mathrm{Mn}$ and $\left.1.0 \mathrm{mg} \mathrm{Ni} / \mathrm{m}^{3}\right)$ or MAC values $\left(0.1 \mathrm{mg} \mathrm{Cd}\right.$ oxide, $0.01 \mathrm{mg} \mathrm{CrO}_{3}, 0.3 \mathrm{mg} \mathrm{Mn}$ and $\left.0.5 \mathrm{mg} \mathrm{Ni} / \mathrm{m}^{3}\right)$.

As oil is a possible source of contamination, the heavy metal content in various oils (used and unused) commonly employed in this industry was examined

Table 1 Heavy metal content of whole blood of autoworkers

\begin{tabular}{|c|c|c|c|c|c|c|c|c|c|c|}
\hline Controls: & \multicolumn{2}{|c|}{$\begin{array}{l}C d \\
(\mu \mathrm{g} / 100 \mathrm{ml})(\mu \mathrm{mol} / \mathrm{l})\end{array}$} & \multicolumn{2}{|c|}{$\begin{array}{l}N i \\
(\mu \mathrm{g} / 100 \mathrm{ml})(\mu \mathrm{mol} / \mathrm{l})\end{array}$} & \multicolumn{2}{|c|}{$\begin{array}{l}M n \\
(\mu \mathrm{g} / 100 \mathrm{ml})(\mu \mathrm{mol} / \mathrm{l})\end{array}$} & \multicolumn{2}{|c|}{$\begin{array}{l}C u \\
(\mu \mathrm{g} / 100 \mathrm{ml})(\mu \mathrm{mol} / \mathrm{l})\end{array}$} & \multicolumn{2}{|c|}{$\begin{array}{l}C r \\
(\mu \mathrm{g} / 100 \mathrm{ml})(\mu \mathrm{mol} / \mathrm{l})\end{array}$} \\
\hline $\begin{array}{l}\text { Controls: } \\
\text { Mean } \\
\text { SD } \\
\text { Range }\end{array}$ & $\begin{array}{r}1.64 \\
\pm 0.85 \\
0.3-4.8\end{array}$ & $\begin{array}{c}0.15 \\
\pm 0.08 \\
0.03-0.43\end{array}$ & $\begin{array}{l}1 \cdot 7 \\
\pm 1 \cdot 5 \\
0 \cdot 4-5 \cdot 4\end{array}$ & $\begin{array}{c}0.29 \\
\pm 0.26 \\
0.07-0.92\end{array}$ & $\begin{aligned} & 5 \cdot 7 \\
&+ 2 \cdot 6 \\
& 0 \cdot 5-9 \cdot 8\end{aligned}$ & $\begin{array}{l}1 \cdot 0 \\
\pm 0.5 \\
0 \cdot 1-1 \cdot 8\end{array}$ & $\begin{array}{c}83 \\
\pm 26 \\
45-162\end{array}$ & $\begin{array}{l}13 \cdot 1 \\
\pm 4 \cdot 1 \\
71-25 \cdot 5\end{array}$ & $\begin{array}{c}4 \cdot 5 \\
\pm 2 \cdot 9 \\
0 \cdot 8-8 \cdot 4\end{array}$ & $\begin{array}{c}0.86 \\
\pm 0.55 \\
0.2-1.6\end{array}$ \\
\hline $\begin{array}{l}\text { Autoworkers: } \\
\text { Mean } \\
\text { SD }\end{array}$ & $\begin{array}{r}1.56 \\
\pm 0.84\end{array}$ & $\begin{array}{r}0.14 \\
\pm 0.08\end{array}$ & $\begin{array}{l}5 \cdot 3 \\
\pm 4 \cdot 8 \\
P<0.01\end{array}$ & $\begin{array}{r}0.90 \\
\pm 0.82\end{array}$ & $\begin{array}{r}5 \cdot 6 \\
\pm 4 \cdot 7\end{array}$ & $\begin{array}{r}1.0 \\
\pm 0.9\end{array}$ & $\begin{array}{r}82 \\
\pm 46\end{array}$ & $\begin{array}{r}12 \cdot 9 \\
\pm 7 \cdot 2\end{array}$ & $\begin{array}{c}5.7 \\
\pm 3.9 \\
P<0.01\end{array}$ & $\begin{array}{r}1 \cdot 10 \\
\pm 0.75\end{array}$ \\
\hline
\end{tabular}

Table 2 Heavy metal content of workshop air*

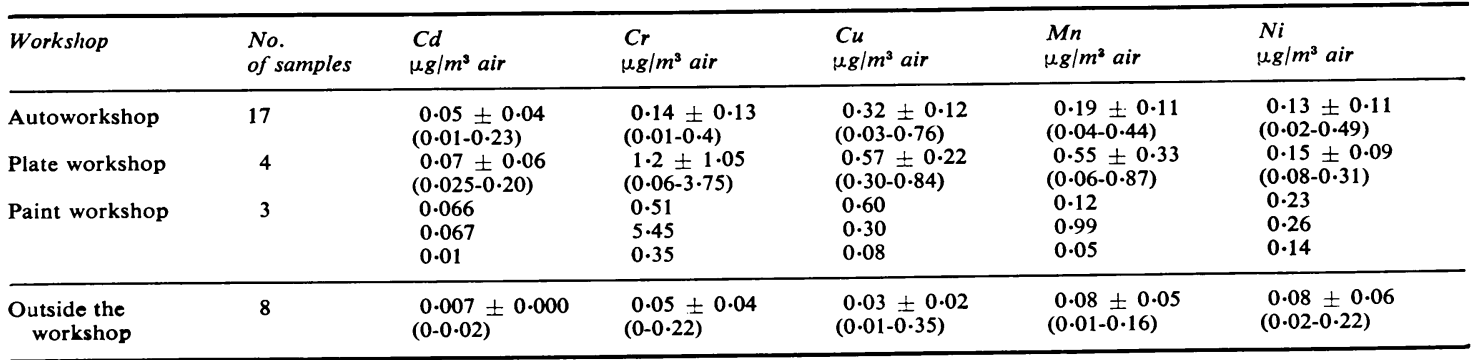

* Range in parentheses 
Table 3 Heavy metal* content of used motor oils

\begin{tabular}{|c|c|c|c|c|c|c|c|}
\hline Car type & Oil & $\begin{array}{l}\text { Motor } \\
\text { driven } \\
(\mathrm{km})\end{array}$ & $\begin{array}{l}\text { Parts } \\
\text { Cd }\end{array}$ & $\begin{array}{c}\text { per million } \\
\mathrm{Cu}\end{array}$ & $\mathrm{Cr}$ & $N i$ & $M n$ \\
\hline $\begin{array}{l}\text { Ford Cortina } 1969 \\
\text { Renault } 4,1973 \\
\text { Mascot } 1965 \\
\text { Datsun } 1973 \\
\text { Ford Taunus 1300, } 1971 \\
\text { Volvo } 142,1973\end{array}$ & $\begin{array}{l}\text { Gulf Multi-G 20-50 } \\
\text { Chevron (type ?) } \\
\text { Mobil Special SAE } 10 \text { W } 50 \\
\text { Mobil Special SAE } 10 \text { W } 50 \\
\text { Esso Uniflow SAE } 10 \text { W } 50 \\
\text { Shell Spirax Gear Oil HD } 80\end{array}$ & $\begin{array}{l}1700 \\
2600 \\
4000 \\
1600 \\
4500 \\
5500\end{array}$ & $\begin{array}{l}1 \cdot 01 \\
1 \cdot 16 \\
0.66 \\
0.94 \\
0.69 \\
0.54\end{array}$ & $\begin{array}{r}18 \cdot 22 \\
25 \cdot 24 \\
19 \cdot 58 \\
7 \cdot 52 \\
5 \cdot 11 \\
11 \cdot 19\end{array}$ & $\begin{array}{l}23 \cdot 49 \\
14 \cdot 09 \\
12 \cdot 36 \\
15 \cdot 55 \\
26 \cdot 45 \\
19 \cdot 01\end{array}$ & $\begin{array}{l}30 \cdot 35 \\
17 \cdot 83 \\
12 \cdot 24 \\
25 \cdot 82 \\
12 \cdot 22 \\
16 \cdot 45\end{array}$ & $\begin{array}{r}10 \cdot 15 \\
8 \cdot 63 \\
3 \cdot 94 \\
2 \cdot 57 \\
5 \cdot 93 \\
2 \cdot 87\end{array}$ \\
\hline
\end{tabular}

*Assayed in triplicate

Table 4 Heavy metal* content of unused oils

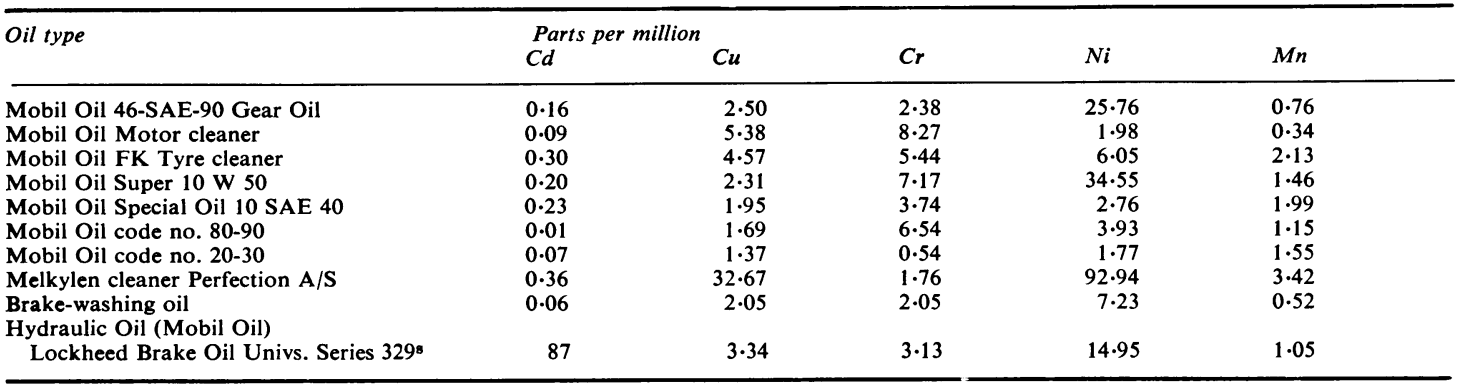

*Assayed in triplicate

(Tables 3 and 4). Some unused oils had a high nickel content, but all the used oils were contaminated with heavy metals.

The cumulative toxic effect (TS) of lead, cadmium, chromium, copper, manganese and nickel pollution in the air together:

$$
\begin{aligned}
& \mathrm{TS}=\frac{\mathrm{C}_{\text {dust }}}{\mathrm{HGV} V_{\text {dust }}}+\frac{\mathrm{C}_{\mathrm{Pb}}}{\mathrm{HGV_{Pb }}}+\frac{\mathrm{C}_{\mathrm{Cd}}}{\mathrm{HGV}_{\mathrm{Cd}}}+\frac{\mathrm{C}_{\mathrm{Cr}}}{\mathrm{HGV}_{\mathrm{Cr}}} \\
& +\frac{\mathrm{C}_{\mathrm{Cu}}}{\mathrm{HGV}_{\mathrm{Cu}}}+\frac{\mathrm{C}_{\mathrm{Mn}}}{\mathrm{HGV}_{\mathrm{Mn}}}+\frac{\mathrm{C}_{\mathrm{Ni}}}{\mathrm{HGV}_{\mathrm{Ni}}}
\end{aligned}
$$

where $\mathrm{C}$ represents the concentration of a metal and HGV the threshold limit value, was below the acceptable limit according to the Danish (1.0) or Swedish standard $(1 \cdot 14)$.

Nineteen per cent of the autoworkers had carboxyhaemoglobin levels of $12 \%$ or more. This may represent a pathological level (Moeschlin, 1972). Seventy-one per cent of the workers with carboxyhaemoglobin values above $12 \%$ complained of dizziness and headache.

No signs of heavy metal pollution other than those described previously (Clausen and Rastogi, 1977) were found in blood samples of the group being studied.

\section{Discussion}

The heavy metal content of whole blood of the control subjects was comparable with those found by Butt et al. (1964), Delves et al. (1971) and Hecker et al. (1974). The group mean of the cadmium and copper content in whole blood from the autoworkers was normal. However, $15 \%$ of the autoworkers had significantly increased levels of manganese. Welding fume is a possible source of this pollution as manganese may be released from metal-coated electrodes during welding. Another source may be the use of methylcyclopentadienyl manganese tricarbonyl used as an additive in machine, diesel and fuel oils (Tolonen, 1972). It may be argued that organic manganese may affect the autoworkers in a way similar to organic lead.

One of the major sources of cadmium pollution may be the burning of crude oil (Fancher, 1973). However, it was not possible to trace any major source of cadmium pollution during the present study and cadmium levels in the whole blood of autoworkers were normal, making it impossible to correlate the high percentage of autoworkers having high blood pressure (Clausen and Rastogi, 1977) with cadmium levels (Carrol, 1966). The level of copper was found to be normal but very variable in the exposed group.

The levels of chromium and nickel in the whole blood of autoworkers were significantly higher than those of the controls. The sources of these metals are not clear. Chromium derivatives are known to be used as pigments in corrosion-protective 
paints and welding of old metal plates coated with such paint may release chromium to the air. Chromium and nickel may also be given off during welding with metal-coated electrodes. When automobile engines are hot it is also possible that lead from leaded motor oils (lead naphthenate) and lubricants may be exchanged with nickel and chromium in steel (from cylinders and other mechanical parts). A release of chromium and nickel into the engine oil may account for the increase in chromium and nickel content of many oils after use. Finally, nickel may be eluted from steel parts by the action of sweat (Samitz and Katz, 1975) and thus be a source of intake for autoworkers.

Knowledge of the toxic effects of heavy metals other than lead is scanty (Albert et al., 1973). Manganese and nickel can, like lead, give rise to peripheral neuropathy and brain damage (Tolonen, 1972). Our recent electrophysiological investigation (Melgaard et al., 1976b) showed peripheral nerve abnormalities in autoworkers with high heavy metal levels. The high levels of nickel, chromium and manganese among the autoworkers underlines the need for scrupulous hygiene in autoworkshops.

Carbon monoxide pollution in the autoworkshops was not abnormally high as indicated by the carboxyhaemoglobin levels in autoworkers. This finding is in agreement with the results obtained by Ljungström (1972) who found that carbon monoxide pollution in autoworkshops ( $35 \mathrm{ppm})$ was not above the Swedish TLV. However, $19 \%$ of the autoworkers had carboxyhaemoglobin values of over $12 \%$, the limit which Moeschlin (1972) found to be pathological for smokers. The group of autoworkers included both smokers and non-smokers and there was no correlation between the level of carboxyhaemoglobin and tobacco consumption.

We wish to express our gratitude to the Commission of the European Communities, whose grant no. 075/74/ENV.DK from the Environmental Research Fund made it possible to carry out these studies. We also wish to thank Mr Erik Østergaard for his skilful technical assistance, the Danish Medical Council and Odense University for financial support in making available the atomic absorption apparatus used and the Danish International Development Agency (DANIDA), whose grant of a research scholarship (D4 JNR 104 P3 Ind 408) made it possible for S. C. Rastogi to perform this work.

\section{References}

Albert, R., Berlin, M., Finklea, J., Friberg, L., Goyer, R. A., Henderson, R., Heinberg, S., Kazantzis, G., Kehoe, R. A., Kolbye, A. C., Magos, L., Miettinen, J. K., Nordberg, G.,
Norseth, T., Pfitzer, E. A., Piscator, M., Shibko, S. I.. Singerman, A., Tsuchiya, K., and Vostal, J. (1973), Accumulation of toxic metals with reference to their absorption, excretion and biological half-times. A task group on metal accumulation. Environmental Physiology and Biochemistry, 3, 65-107.

Bauer, J. D., Ackermann, P. G., and Toro, G. (1974). Methods in hematology. In Clinical Laboratory Methods, p. 93. Mosby: St. Louis.

Butt, E. M., Nusbaum, R. E., Gilmour, T. C., Didio, S. L., and Marino, S. (1964). Trace metal levels in human serum and blood. Archives of Environmental Health, 8, 52-57.

Carrol, R. E. (1966). The relationship of cadmium in the air to cardiovascular disease death rates. Journal of the American Medical Association, 198, 267-269.

Clausen, J., and Rastogi, S. C. (1977). Heavy metal pollution among autoworkers. I. Lead. British Journal of Industrial Medicine, 34, 208-215.

Delves, H. T., Shepherd, G., and Vinter, P. (1971). Determination of eleven metals in small samples of blood by sequential solvent extraction and atomic absorption spectrophotometry. Analyst, 96, 260-273.

Evans, G. M. (1973). Copper homeostasis in mammalian system. Physiological Reviews, 53, 535-570.

Fancher, J. R. (1973). Trace element emissions from the combustion of fossil fuels. In Cycling and Control of Metals, p. 88. Edited by M. G. Curry and G. M. Gigliotti. National Environmental Research Council: Cincinnati.

Fassett, D. W. (1975). Cadmium: biological effects and occurrence in the environment. Annual Review of Pharmaco$\log y, 15,425-436$.

Fleischer, M., Sarofim, A. F., Fassett, D. W., Hammond, P., Schacklette, H. T., Nisbet, I. C., and Epstein, S. (1974). Environmental impact of cadmium: a review by the panel on hazardous trace substances. Environmental Health Perspectives, 7, 263-323.

Fleming, C. R., Dickson, E. R., Baggenstoss, A. H., and McCall, J. T. (1974). Copper and primary biliary cirrosis. Gastroenterology, 67, 1182-1187.

Haar, G. L. T., Griffig, M. G., Brandt, M., Oberding, D. G., and Kapson, M. (1975). Methylcyclopentadienyl manganese tricarbonyl as an antiknock: composition and fate of manganese exhaust product. Journal of the Air Pollution Control Association, 28, 858-860.

Hecker, L. H., Allen, H. E., Dinman, B. D., and Neel, J. V. (1974). Heavy metal levels in acculturated and unacculturated populations. Archives of Environmental Health, 29, 181-185.

Jonderko, G., Kujawska, A., and Langauer-Lewowicka, H. (1971). Problems of chronic manganese poisoning on the basis of investigation of workers at a manganese alloy foundry. Internationales Archiv für Arbeitsmedizin, 29, 250-264.

Ljungström, G. (1972). Arbetsmiljön på verkstäderne. Motorbranschen, 14, 787-788.

McHowell, J. C., Blakemore, W. F., Gopinath, C., Hall, G. A., and Parker, J. H. (1974). Chronic copper poisoning and changes in central nervous system of sheep. Acta Neuropathologica, 29, 9-24.

McNeely, M. D., Sunderman, F. W., Nechay, F. W., and Levine, H. (1971). Abnormal concentrations of serum nickel in myocardial infarction, cerebral stroke, burns, hepatic cirrhosis and uremia. Clinical Chemistry, 17, 1123-1126.

Melgaard, B., Clausen, J., and Rastogi, S. C. (1976a). Heavy metal levels and delta-aminolevulinic acid dehydrase levels in peripheral polyneuropathy. Acta Neurologica Scandinavica, 53, 291-307.

Melgaard, B., Clausen, J., and Rastogi, S. C. (1976b). 
Abnormalities in peripheral nerves of automechanics with increased heavy metals. Acta Neurologica Scandinavica, 54, 227-240.

Moeschlin, S. (1972). Klinik und Therapie der Vergiftungen. George Thieme Verlag: Stuttgart.

Ottolenghi, A. D., Haseman, J. K., Payne, W. W., Falk, H. L., and McFarland, H. N. (1974). Inhalation studies of nickel sulfide in pulmonary carcinogenesis. Journal of the National Cancer Institute, 54, 1165-1172.

Royle, H. (1975a). Toxicity of chromic acid in the chromium plating industry (1). Environmental Research, 10, 39-53.

Royle, H. (1975b). Toxicity of chromic acid in the chromium plating industry (2). Environmental Research, 10, 141-163.

Samitz, M. H., and Katz, S. A. (1975). Nickel dermatitis hazards from prostheses: in vivo and in vitro solubiliza- tion studies. British Journal of Dermatology, 92, 287-290.

Sanderson, J. T. (1968). Hazards of the arc-air gouging process. Annals of Occupational Hygiene, 11, 123-133.

Schoental, R. (1975). Chromium carcinogenesis: formation of epoxyaldehydes and tanning. British Journal of Cancer, 32, 403-404.

Steel, J. (1968). Respiratory hazards in ship-building and ship preparing. Annals of Occupational Hygiene, 11, 115-121.

Tolonen, M. (1972). Industrial toxicity of manganese. Work-Environment-Health, 9, 53-60.

World Health Organization (1969). Urban air pollution with particular reference to motor vehicles. Report of a WHO Expert Committee. Technical Report Series No. 410. WHO: Geneva.

\section{The May 1977 Issue}

\section{THE MAY 1977 ISSUE CONTAINS THE FOLLOWING PAPERS}

Radiological assessment of small pneumoconiotic opacities F. D. K. LIDDELL

Energy dispersive $x$-ray analysis in the study of pneumoconiosis A. FUNAHASHI, K. A. SIEGESMUND, R. F. DRAGEN, AND K. PINTAR

Cancers of the lung and nasal sinuses in nickel workers: a reassessment of the period of risk $R$. DOLL, J. D. MATHEWS, AND L. G. MORGAN

Application of blood cadmium analysis to industry using an atomic fluorescence method G. S. FELL, J. M. OTTAWAY, AND F. E. R. HUSSEIN

The effect of zinc and $\mathrm{pH}$ on the behaviour of $\delta$ aminolevulinic acid dehydratase activity in baboons exposed to lead A. C. CANTRELl, T. A. KILROESMITH, M. M. SIMÕES, AND E. A. BORDER

Occupational exposure to manganese M. ŠARIĆ, A. MARKIĆEVIĆ, AND O. HRUSTIĆ

Antagonistic activity of poly (4-vinylpyridine-Noxide) to the inhibition of viral interferon induction by asbestos fibres N. HAHON, J. A. BOOTH, AND H. L. ECKERT
Acceptable levels for the breathing resistance of respiratory apparatus: results for men over the age of 45 R. G. LOVE, D. C. F. MUIR, K. F. SWEETLAND, R. A. BENTLEY, AND O. G. GRIFFIN

Effects of fluorocarbon propellants on respiratory flow and ECG F. VALIĆ, ZDENKA SKURIĆ, ž. BANTIĆ, M. RUDAR, AND M. HEĆEJ

Efficiency and daily work effort in sugar cane cutters G. B. SPURR, M. BARAC-NIETO, AND M. G. MAKSUD

Screening for liver disease in vinyl chloride workers F. I. LEE, D. S. HARRY, W. G. F. ADAMS, AND M. LITCHFIELD

Notes and miscellanea

The effect of twelve-hour shift working on absence attributed to sickness

A. WARD GARDNER AND B. D. DAGNALL

Book reviews

Information section

Copies are still available and may be obtained from the PUBLISHING MANAGER, BRITISH MEDICAL ASSOCIATION, TAVISTOCK SQUARE, LONDON, WClH 9JR, price $£ 3 \cdot 75$, (USA $\$ 9 \cdot 20$ ) including postage 